\title{
Influence of Composted Municipal Sludge on Efficiency of Primary Nutrients in Maize (Zea mays L.) under Temperate Himalayas
}

\author{
M. Auyoub Bhat*, J.A. Wani and Sandeep Kumar \\ Division of Soil Science, S.K. University of Agricultural Sciences \& Technology of Kashmir, \\ Srinagar, Jammu \& Kashmir 191121, India \\ *Corresponding author
}

\begin{tabular}{|l|}
\hline Ke y w o r d s \\
$\begin{array}{l}\text { Composted sludge, } \\
\text { Economic efficiency, } \\
\text { Agronomic efficiency, } \\
\text { Recovery efficiency, } \\
\text { Chemical fertilizers }\end{array}$ \\
\hline Article Info \\
$\begin{array}{l}\text { Accepted: } \\
\text { 06 May } 2018 \\
\text { Available Online: } \\
\text { 10 June } 2018\end{array}$ \\
\hline
\end{tabular}

\section{Introduction}

The rampant use of chemical fertilizers contributes to the deterioration of the environment through depletion of fossil fuels, generation of carbon dioxide and contamination of water resources. It also leads to loss of soil fertility due to imbalanced use of plant nutrients that adversely impacts

\section{A B S T R A C T}

Field experiments were conducted at the Agricultural Research Farm of Krishi Vigyan Kendra, SKUAST-K, Shuhama, Srinagar to study the effect of composted municipal sludge application on efficiency of primary nutrients viz. nitrogen, phosphorus and potassium in maize (Zea mays L.). Application of 75\% NPK + sludge @ $30 \mathrm{t} \mathrm{ha}^{-1}$ resulted in highest yields and nutrient uptake by the crop followed by NPK + sludge @ $15 \mathrm{t} \mathrm{ha}^{-1}$, 75\% NPK + sludge@ $15 \mathrm{t} \mathrm{ha}^{-1}$ and 50\% NPK + 30 sludge @ $30 \mathrm{t} \mathrm{ha}^{-1}$. These were statistically identical to each other for seed and stover yields. Highest agronomic efficiency of nitrogen, phosphorus and potassium was observed in 50\% NPK + Sludge @ $30 \mathrm{t} \mathrm{ha}^{-1}$ followed by 50\% NPK + Sludge @ $15 \mathrm{t} \mathrm{ha}^{-1}, 75 \%$ NPK + Sludge @ $30 \mathrm{t} \mathrm{ha}^{-1}, 75 \%$ NPK + Sludge @ $15 \mathrm{t} \mathrm{ha}^{-1}$, NPK + Sludge @ $15 \mathrm{t} \mathrm{ha}^{-1}$ and NPK. Recovery efficiency of nitrogen, phosphorus and potassium was maximum in $75 \% \mathrm{NPK}+$ Sludge @ $30 \mathrm{t} \mathrm{ha}^{-1}$ followed by NPK + Sludge@15 tha ${ }^{-1}, 75 \%$ NPK + Sludge@15 t ha ${ }^{-1}, 50 \%$ NPK + Sludge @30 t $\mathrm{ha}^{-1}$, NPK and 50\% NPK + Sludge @ $15 \mathrm{t} \mathrm{ha}^{-1}$. Highest physiological efficiency of nitrogen, phosphorus and potassium was recorded in 50\% NPK + Sludge @ $15 \mathrm{t} \mathrm{ha}^{-1}$ followed by NPK, 50\% NPK + Sludge @ $30 \mathrm{t} \mathrm{ha}^{-1}$ and 75\% NPK + Sludge @ $15 \mathrm{t} \mathrm{ha}^{-1}$. Highest economic efficiency of nitrogen, phosphorus and potassium was registered with $50 \%$ NPK + Sludge @ $30 \mathrm{t} \mathrm{ha}^{-1}$ followed by $50 \%$ NPK + Sludge @ $15 \mathrm{t} \mathrm{ha}^{-1}, 75 \%$ NPK + Sludge@30 tha ${ }^{-1}, 75 \%$ NPK + Sludge@ $15 \mathrm{tha}^{-1}, 75 \% \mathrm{NPK}+$ Sludge @ $15 \mathrm{tha}^{-1}$, NPK + Sludge @ $15 \mathrm{t} \mathrm{ha}^{-1}$ and NPK. The results clearly indicated that use of composted sludge could increase the efficiency of primary nutrients and decrease the requirement of NPK fertilizers by 25-50 percent under temperate Himalayas. 
and urbanization, per capita generation of municipal wastes with each passing day has tremendously been increasing. Most of these wastes are used for unscientific land-filling or uncontrolled dumping in towns and cities which have serious environmental implications in global warming through emission of greenhouse gases (Paramasivam et al., 2008).

Use of chemical, physical and biological properties of soil as a living filter appears a solution to soil and water pollution resulting from the present waste disposal processes. Agricultural lands are excellent sites for beneficially using municipal sludge as a conditioner/fertilizer containing organic matter and plant nutrients (Sommers, 1977; Casado-Vela et al., 2006, 2007).

The application of sludge to agricultural land can prove to be an excellent substitute for costly fertilizer inputs and can be cost effective for both the municipalities generating this product and the farmers who accept it.

Integrated plant nutrient is a concept that aims at managing and supplying nutrients to plants through chemical fertilizers as well as all possible organic sources to an optimum level for sustaining a desired crop productivity with simultaneous conservation of natural resources and maintenance of environmental quality (Milkha, 2010). It is more realistic to use a management system that will incorporate sludge and chemical fertilizers in suitable ratios in a specific crop improvement programme to realize sustained results. In view of these points, field experiments were carried out to investigate the influence of composted municipal sludge on efficiency of nitrogen, phosphorus and potassium in maize which being one of the dominant crops cultivated by farmers in hilly areas of temperate Himalayas.

\section{Materials and Methods}

The present study was undertaken at Agricultural Research Farm of Krishi Vigyan Kendra, SKUAST-K, Shuhama, Srinagar $\left(34^{0}\right.$ $11^{\prime} \mathrm{N}, 74^{0} 49^{\prime} \mathrm{E}, 1631 \mathrm{~m}$ amsl). The soil of the experimental location was silty clay loam in texture with initial $\mathrm{pH} 7.2$, electrical conductivity $0.12 \mathrm{dS} \mathrm{m}^{-1}$, organic carbon $5.4 \mathrm{~g}$ $\mathrm{kg}^{-1}$, available $\mathrm{N}, \mathrm{P}, \mathrm{K}$ and DTPA-extractable $\mathrm{Zn}, \mathrm{Cu}, \mathrm{Mn}$ and $\mathrm{Fe} 210,16.6,311,1.1,2.0$, 12.8 and $14.2 \mathrm{~kg} \mathrm{ha}^{-1}$, respectively. The experiment was arranged in a completely randomized block design with seven treatments in three replications in plots of $5 \mathrm{~m}$ x 3 m size with maize (Zea mays L., cv. 'Super Maize' composite) as a test crop. The treatment details were, $\mathrm{T}_{1}$ : Control; $\mathrm{T}_{2}$ : NPK (recommended fertilizer dose); $\mathrm{T}_{3}: \mathrm{NPK}+$ sludge@15 tha ${ }^{-1} ; \mathrm{T}_{4}: 50 \%$ NPK + sludge@ $15 \mathrm{t} \mathrm{ha}^{-1} ; \mathrm{T}_{5}: 50 \% \mathrm{NPK}+$ sludge @ $30 \mathrm{t} \mathrm{ha}^{-1}$; $\mathrm{T}_{6}: 75 \% \mathrm{NPK}+$ sludge @ $15 \mathrm{t} \mathrm{ha}^{-1}$; and $\mathrm{T}_{7}$ : $75 \%$ NPK + sludge @ $30 \mathrm{tha}^{-1}$.

The recommended fertilizer dose according to soil test based fertilizer recommendation was $120 \mathrm{~kg} \mathrm{~N}, 60 \mathrm{~kg} \mathrm{P}_{2} \mathrm{O}_{5}$ and $40 \mathrm{~kg} \mathrm{~K}_{2} \mathrm{O} \mathrm{ha}^{-1}$. The sludge was collected in bulk from a waste water treatment plant located in Hazratbal, Srinagar and subjected to composting process for period of four months in trenches. As per treatments, air dried composted sludge was incorporated into plots fifteen days before sowing of the crop. The characteristics of sludge used in the experiment are given in Table 1.

The NPK fertilizers as per treatments were applied through urea, diammonium phosphate and muriate of potash at the time of sowing. Nitrogen supplied via diammonium phosphate was adjusted in urea. The crop was harvested at maturity and grain and stover yields were recorded. The nitrogen content in composted sludge and plant samples was determined by Kjeldahl method (Jackson, 1973). Composted 
sludge and plant samples were digested in 2:1 $\mathrm{HNO}_{3}-\mathrm{HClO}_{4}$ mixture (Jackson, 1973) and in the extracts phosphorus was determined by calorimetry and potassium by flame photometry. The agronomic, recovery, physiological and economic efficiency of nutrients were calculated as follows (Mosier et al., 2004):

\section{Agronomic efficiency (AE) of nutrients}

It is refers to increase in economic (seed) yield per unit of nutrient $(\mathrm{N}, \mathrm{P}, \mathrm{K})$ applied i.e. it is the ratio of seed yield to the amount of nutrient applied and is expressed as $\mathrm{kg} \mathrm{kg}^{-1}$.

(Seed yield in fertilized plot -

Seed yield in control plot)

$\mathrm{AE}=$

Nutrient dose applied

\section{Recovery Efficiency (RE) of nutrients}

It refers to the increase in the nutrient uptake by plant (seed plus stover) per unit of nutrient $(\mathrm{N}, \mathrm{P}, \mathrm{K})$ applied. The recovery efficiency is generally expressed in percent $(\%)$.

(Nutrient uptake in fertilized plot -

Nutrient uptake in control plot)

RE = ------------ x 100

\section{Physiological Efficiency (PE) of nutrients}

It indicates the efficiency with which the crop utilizes the absorbed nutrients to produce economic yield. It is the ratio of the increase in yield to the increase in nutrient uptake and expressed as $\mathrm{kg} \mathrm{kg}^{-1}$.

\footnotetext{
(Seed yield in fertilized plot Seed yield in control plot)$$
\begin{gathered}
\text { PE }=\text { Nutrient uptake in fertilized plot - } \\
\text { Nutrient uptake in control plot) }
\end{gathered}
$$

\section{Economic Efficiency (EE) of nutrients}

When agronomic efficiency (AE) is expressed in monetary terms, it becomes economic efficiency. It can be equated with most popularly used benefit: cost ratio and is calculated as

$$
\mathrm{EE}=\frac{\text { Value of produce }(\mathrm{Rs})}{\text { Cost of applied nutrient dose }}
$$

\section{Results and Discussion}

\section{Crop yields}

A perusal of the results presented in Table 2 shows that application of $75 \% \mathrm{NPK}+$ sludge (a) $30 \mathrm{t} \mathrm{ha}^{-1}$ gave highest yields of grain (46.3 $\left.\mathrm{q} \mathrm{ha}^{-1}\right)$ and strover $\left(72.7 \mathrm{q} \mathrm{ha}^{-1}\right)$ followed by NPK + sludge @ $15 \mathrm{t} \mathrm{ha}^{-1}, 75 \%$ NPK + sludge @ $15 \mathrm{t} \mathrm{ha}^{-1}$ and $50 \% \mathrm{NPK}+30$ sludge @ $30 \mathrm{t}$ $\mathrm{ha}^{-1}$. These were at par to each other for the seed and stover yield. Higher yields due to integration of sludge and chemical fertilizers could be explained on the basis of improved physical and nutritional environment of the soil under study and increased availability of nutrients by the crop. Many researchers have also reported improved crop yields and reduced commercial fertilizer requirements with the application of sewage sludge. Antolin et al., (2005) reported that the yield of barley increased in sludge and fertilizer amended plots compared to unamended plots. Al Zoubi et al., (2008) related higher productivity of maize to better physical and nutritional properties of soil caused by the sludge application. Tamrabet et al., (2009) found that $30 \mathrm{t} \mathrm{ha}^{-1}$ of sewage sludge was as efficient as $66 \mathrm{~kg} \mathrm{ha}^{-1}$ of mineral nitrogen in increasing the grain and straw yields of wheat. Bhat (2010) reported enhanced dry matter yields and decreased toxicities of heavy metals in maize and radish with increasing levels of biosolid application to soil. 
Table.1 Characteristics of composted sludge

\begin{tabular}{|l|}
\hline Parameter \\
\hline Particle size $(\mathrm{mm})$ \\
\hline Moisture content $(\%)$ \\
\hline Odour \\
\hline Colour \\
\hline Bulk density $\left(\mathrm{g} \mathrm{cc}^{1}\right)$ \\
\hline pH $(1: 2.5)$ \\
\hline EC $\left(\mathrm{dS} \mathrm{m}{ }^{-1}\right)$ \\
\hline OC $\left(\mathrm{g} \mathrm{kg}{ }^{-1}\right)$ \\
\hline Total N $\left(\mathrm{g} \mathrm{kg}^{-1}\right)$ \\
\hline Total P $\left(\mathrm{g} \mathrm{kg}^{-1}\right)$ \\
\hline Total K $\left(\mathrm{g} \mathrm{kg}^{-1}\right)$ \\
\hline Total Zn $\left(\mathrm{mg} \mathrm{kg}^{-1}\right)$ \\
\hline Total Cu $\left(\mathrm{mg} \mathrm{kg}^{-1}\right)$ \\
\hline Total $\mathrm{Mn}\left(\mathrm{mg} \mathrm{kg}^{-1}\right)$ \\
\hline Total Fe $\left(\mathrm{mg} \mathrm{kg}^{-1}\right)$ \\
\hline
\end{tabular}

\begin{tabular}{|c|}
\hline Value \\
\hline 2.0 \\
\hline 31.5 \\
\hline Earthy \\
\hline Dark brown \\
\hline 0.83 \\
\hline 6.55 \\
\hline 4.7 \\
\hline 116.5 \\
\hline 17.5 \\
\hline 0.95 \\
\hline 12 \\
\hline 563.5 \\
\hline 526.5 \\
\hline 591.5 \\
\hline 11470 \\
\hline
\end{tabular}

Table.2 Effect of differential doses of composted sludge and fertilizers on yield and nutrient uptake of maize (pooled data of two years)

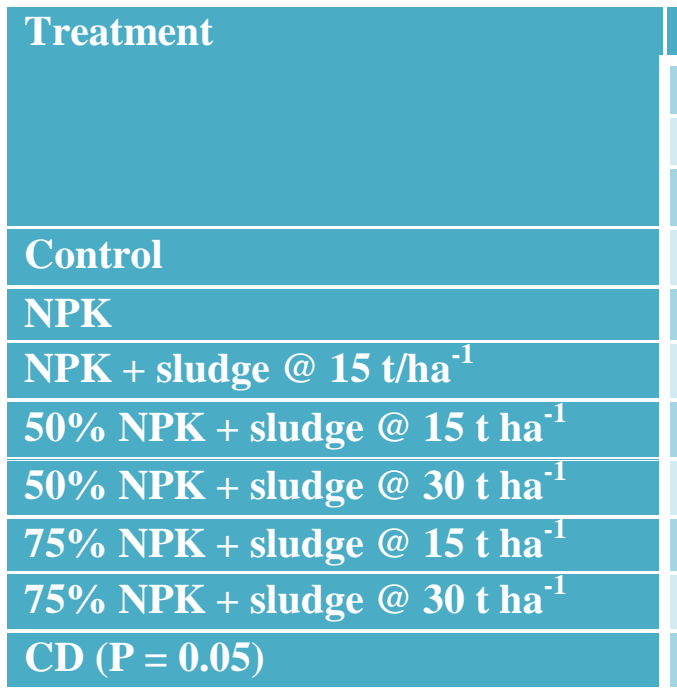

\begin{tabular}{|c|c|c|c|c|}
\hline \multicolumn{2}{|c|}{ Yield } & \multicolumn{3}{c|}{ Uptake } \\
\hline Grain & Stover & \multicolumn{3}{c|}{ Grain + Stover } \\
\hline \multicolumn{2}{|c|}{$\left(\mathrm{q} \mathrm{ha}^{-1}\right)$} & & \multicolumn{3}{|c|}{$\left(\mathrm{kg} \mathrm{ha}^{-1}\right)$} \\
\hline 7.3 & 26.8 & 14.9 & 3.4 & 29.2 \\
\hline 35.7 & 64.3 & 79.9 & 18.9 & 100.4 \\
\hline 43.6 & 71.4 & 108.8 & 28.7 & 137.2 \\
\hline 33.8 & 62.2 & 72.4 & 17.7 & 94.3 \\
\hline 38.2 & 65.4 & 89.2 & 22.8 & 111.5 \\
\hline 40.0 & 67.2 & 95.9 & 25.1 & 120.4 \\
\hline 46.3 & 72.7 & 116.9 & 30.1 & 147.2 \\
\hline 6.3 & 15.8 & 2.6 & 0.6 & 4.7 \\
\hline
\end{tabular}


Fig.1

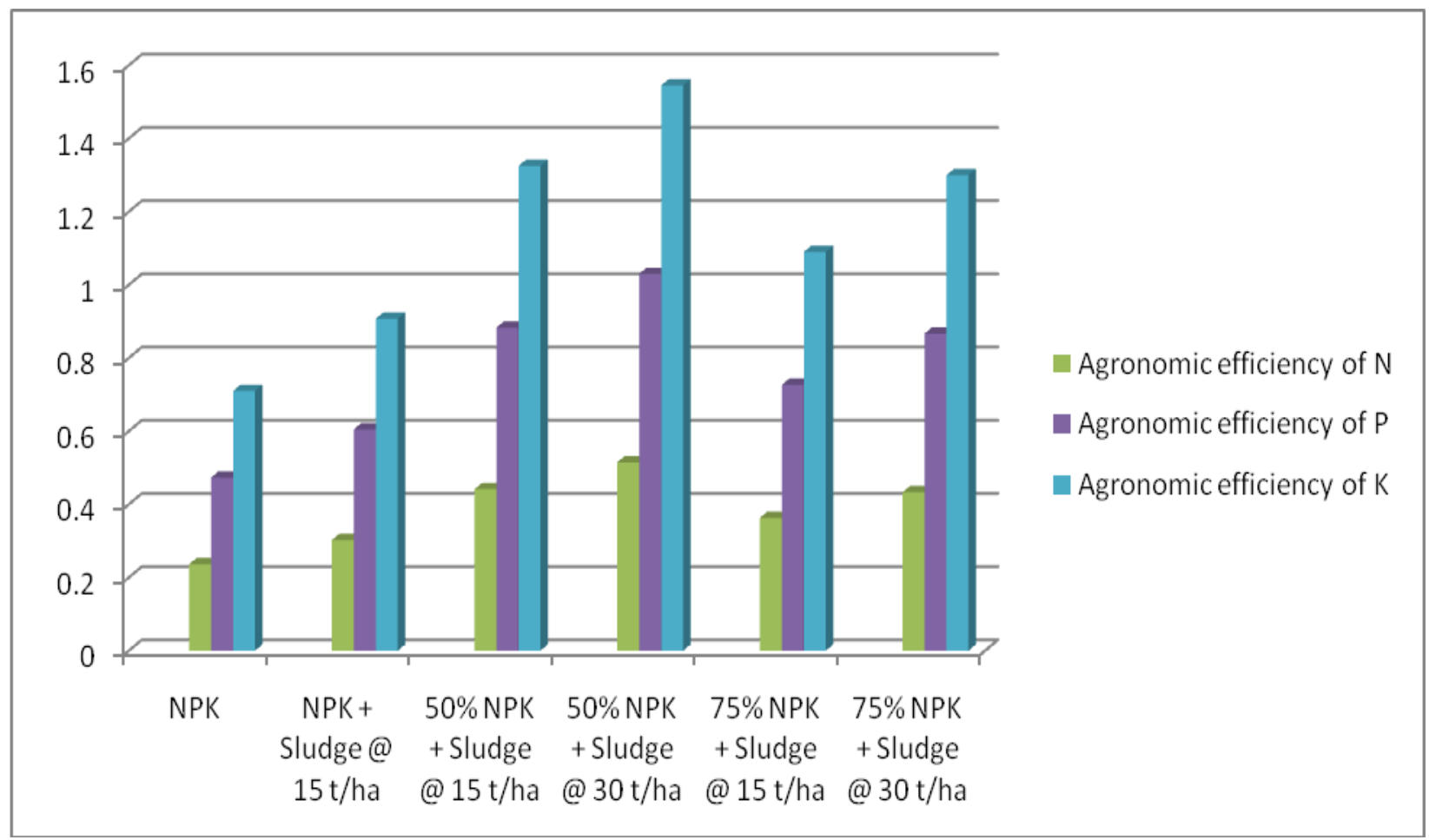

Fig.2

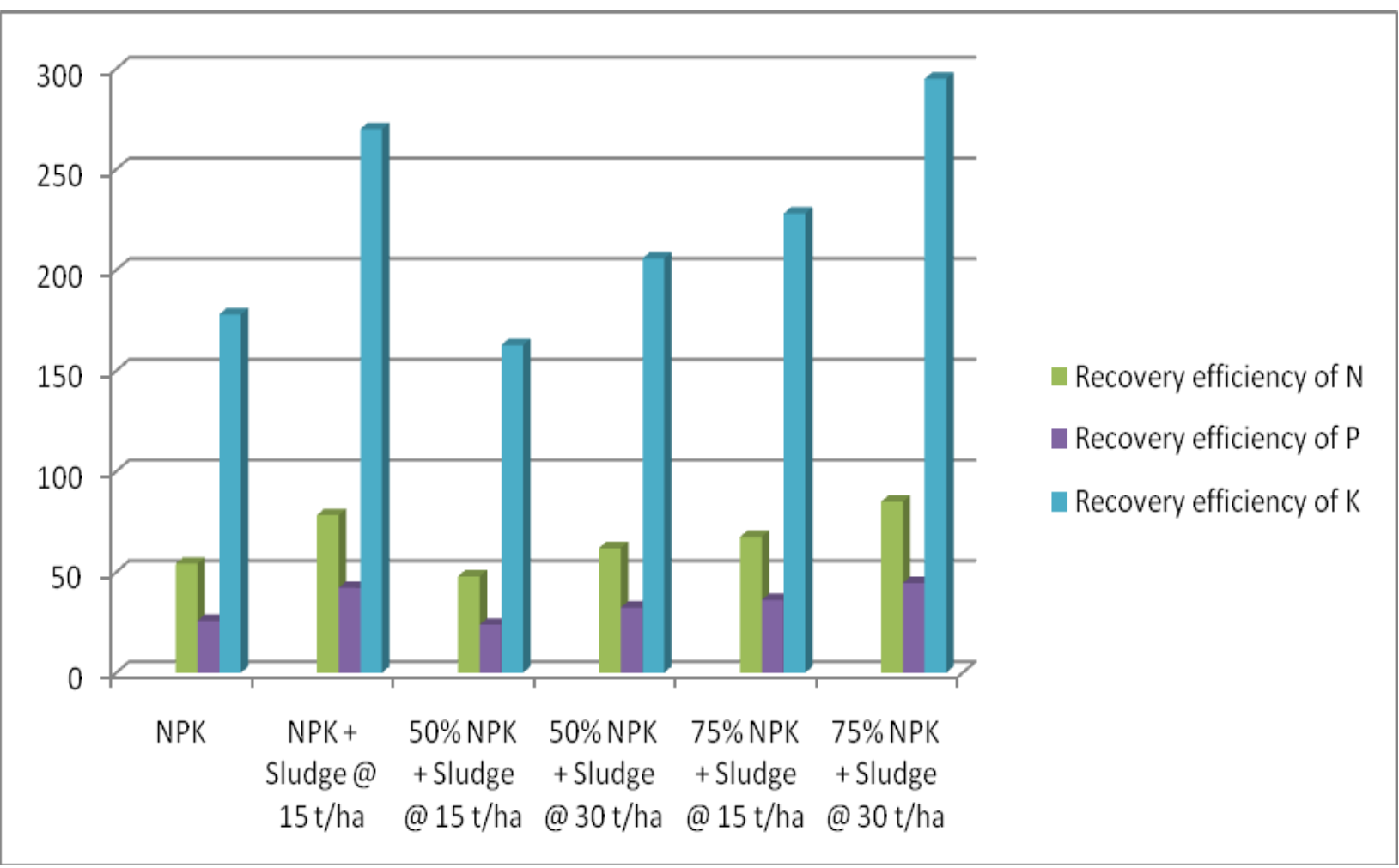


Fig.3

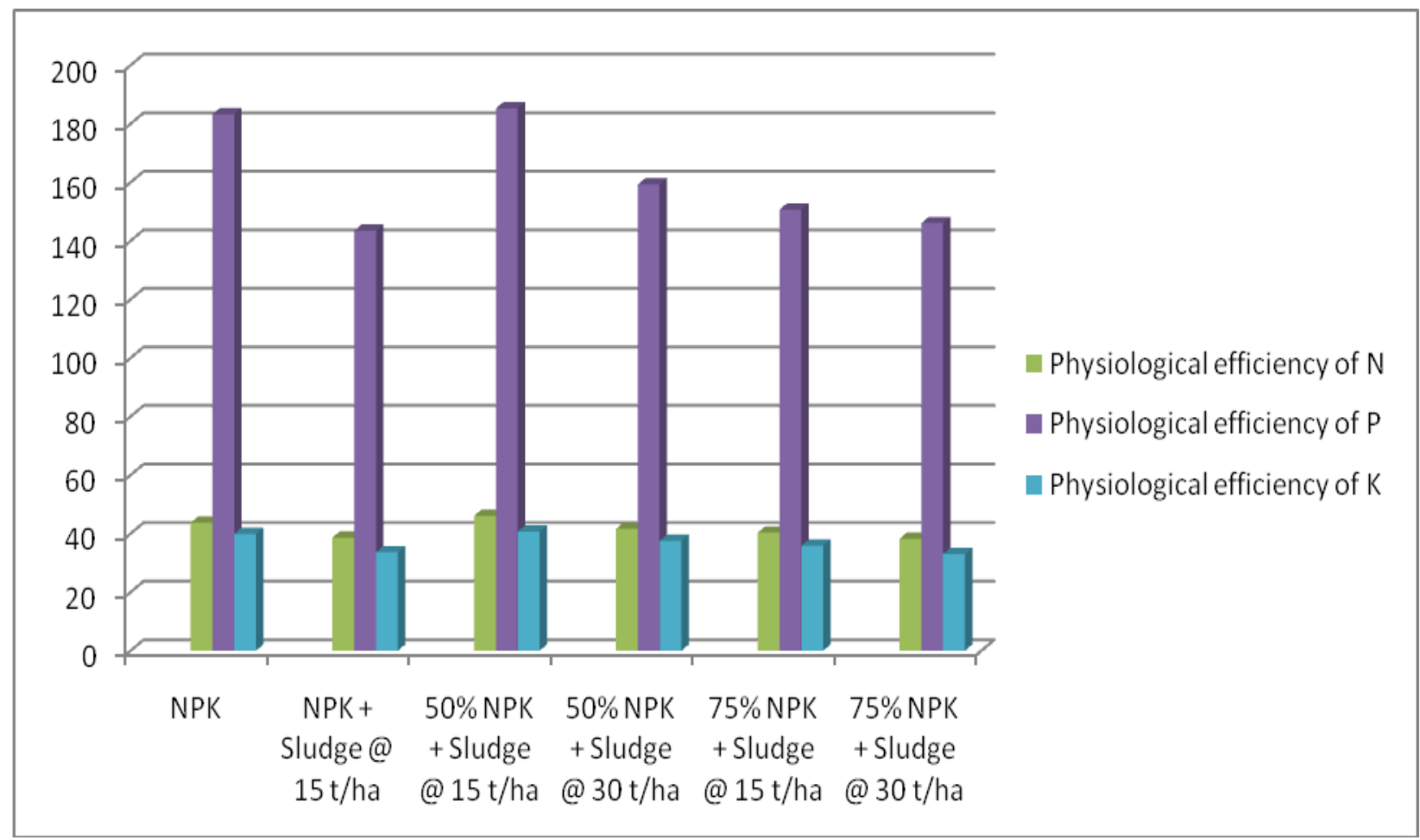

Fig.4

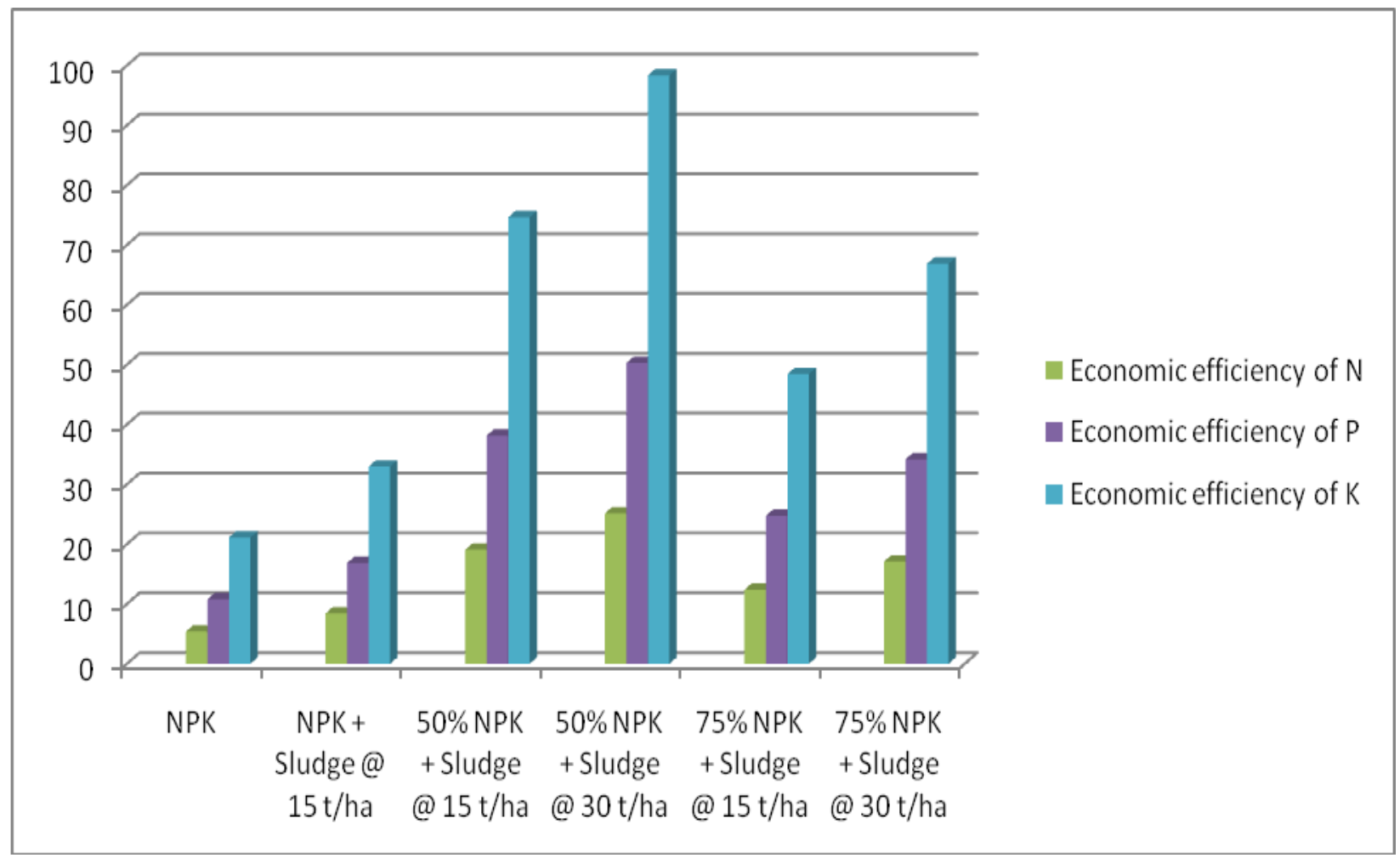




\section{Uptake of primary nutrients}

The maximum total uptake of nutrients by seed plus stover of the crop (116.9 kg N, 30.1 $\mathrm{kg} \mathrm{P}, 147.2 \mathrm{~kg} \mathrm{~K} \mathrm{ha}^{-1}$ was noticed in $75 \%$ NPK + Sludge @ $30 \mathrm{tha}^{-1}$, NPK + Sludge @ $15 \mathrm{tha}^{-1}, 75 \% \mathrm{NPK}+$ Sludge @ $15 \mathrm{tha}^{-1}$ and 50\% NPK + Sludge@ $@ 30 \mathrm{t} \mathrm{ha}^{-1}$ (Table 2). Increased uptake of nutrients could be assigned to enhanced nutrient use efficiency on account of integrated use of composted sludge and chemical fertilizers. Rathod et al., (2013) stated that the beneficial effect of organic manures on nutrient availability was probably due to the solubilization of native nutrients by organic acids released during microbial decomposition of organic materials. Daur et al., (2015) showed that increasing levels of organic manure and humic acid enhanced nutrient uptake in berseem. The results are also in agreement with the findings of Mitchell et al., (1978), Paulraj and Sree Ramulu (1994), Christodoulakis and Margaris (1996), Aggelides and Londra (2000), Mahdy et al., (2007) and N'Dayegamiye (2009).

\section{Efficiency of primary nutrients}

Improvement in nutrient use efficiency has become a desirable goal in crop production enabling efficient nutrient utilization, maximum energy conservation and profitability (Chen et al., 2013). Fixen (2006) suggested that the value of improving nutrient use efficiency is dependent on the effectiveness in meeting the objectives of nutrient use, providing economical optimum nourishment to the crop, minimizing nutrient losses from agricultural fields and contribution to system sustainability through fertility or other quality components of soil. Results in Figure 1 depict that 50\% NPK + Sludge @ $30 \mathrm{t} \mathrm{ha}^{-1}$ registered highest agronomic efficiency of nutrients $(0.515 \mathrm{~kg}$ seed $\mathrm{kg}^{-1} \mathrm{~N}$ applied, $1.03 \mathrm{~kg}$ seed $\mathrm{kg}^{-1} \mathrm{P}$ applied and $1.545 \mathrm{~kg}$ seed $\mathrm{kg}^{-1} \mathrm{~K}$ applied) followed by $50 \%$ NPK + Sludge @ $15 \mathrm{t} \mathrm{ha}^{-1}$, 75\% NPK + Sludge @ $30 \mathrm{t} \mathrm{ha}^{-1}, 75 \% \mathrm{NPK}+$ Sludge@ $15 \mathrm{tha}^{-1}$, NPK + Sludge @ $15 \mathrm{tha}^{-1}$ and NPK. Highest recovery efficiency of N, $\mathrm{P}, \mathrm{K}(85,44.5$ and $295 \%$, respectively) was observed with the application of $75 \%$ NPK + Sludge @ $30 \mathrm{t} \mathrm{ha}^{-1}$ followed by NPK + Sludge@15 tha ${ }^{-1}, 75 \%$ NPK + Sludge@15 $\mathrm{t} \mathrm{ha}^{-1}, 50 \% \mathrm{NPK}+$ Sludge @ $30 \mathrm{tha}^{-1}$, NPK and 50\% NPK + Sludge @ $15 \mathrm{t} \mathrm{ha}^{-1}$ (Figure 2). Highest physiological efficiency of nutrients $\left(46.087 \mathrm{~kg}\right.$ seed $\mathrm{kg}^{-1} \mathrm{~N}$ absorbed, $185.315 \mathrm{~kg}^{-1}$ seed $\mathrm{kg}^{-1} \mathrm{P}$ absorbed and 40.707 $\mathrm{kg}$ seed $\mathrm{kg}^{-1} \mathrm{~K}$ absorbed) was recorded with the application of 50\% NPK + Sludge @ $15 \mathrm{t}$ ha $^{-1}$ followed by NPK, 50\% NPK + Sludge @ $30 \mathrm{tha}^{-1}$ and $75 \% \mathrm{NPK}+$ Sludge @ $15 \mathrm{tha}^{-1}$ (Figure 3). However, physiological efficiency of $\mathrm{N}$ and $\mathrm{K}$ was greater and that of $\mathrm{P}$ lower in NPK + Sludge @ $15 \mathrm{t}$ compared to 75\% NPK + Sludge @ $30 \mathrm{t} \mathrm{ha}^{-1}$. It is depicted in Figure 4 that the economic efficiency of N, P and $\mathrm{K}$ (25.137, 50.273, 98.345, respectively) was maximum in 50\% NPK + Sludge @ $30 \mathrm{t} \mathrm{ha}^{-1}$ followed by $50 \%$ NPK + Sludge @ $15 \mathrm{t} \mathrm{ha}^{-1}$, 75\% NPK + Sludge @ $30 \mathrm{tha}^{-1}, 75 \% \mathrm{NPK}+$ Sludge @ $15 \mathrm{tha}^{-1}, 75 \%$ NPK + Sludge @ 15 $\mathrm{t} \mathrm{ha}^{-1}$, NPK + Sludge @ $15 \mathrm{t} \mathrm{ha}^{-1}$ and NPK.

Improving nutrient efficiency is a major challenge faced by the agriculture all over the world. One of the methods to improve the efficiency of applied nutrients is to recycle municipal sludge and apply it to agricultural land. The results revealed that use of composted sludge could decrease the requirement of primary fertilizer nutrients by 25-50 percent to sustain the productivity of maize under temperate Himalayas.

\section{References}

Aggelides, S.M. and Londra, P.A. 2000. Effects of compost produced from town wastes and sewage sludge on the physical properties of a loamy and a 
clay soil. Bioresource and Technology 71: 253-259.

Al Zoubi, M.M., Arslan, A., Abdelgawad, G., Pejon, N., Tabbaa, M. and Jouzdan, O. 2008. The effect of sewage sludge on productivity of a crop rotation of wheat, maize and vetch and heavy metal accumulation in soil and plant in Aleppo Governorate. American-Eurasia Journal of Agricultural and Environmental Sciences 3: 618-625.

Antolin, M.C., Pascual, I., Garcia, A., Polo, C. and Sanchez Diaz, M. 2005. Growth, yield and solute content of barley in soils treated with sewage sludge under semiarid Mediterranean conditions. Field Crop Research 94: 224-237.

Bhat, M.A. 2010. Effect of digested biosolids and high levels of cadmium and nickel on phytotoxicity and their concentrations in maize and radish. Indian Journal of Ecology 37: 149-152.

Casado-Vela, J., Sellés, S., Diaz-Crespo, C., Navarro-Pedreno, J., Mataix-Beneyto, J. and Gomez, I. 2007. Effcet of composted sewage sludge application to soil on sweet pepper crop (Capsicum annuum var. annuum) grown under two exploitation regimes. Waste Management 27: 1509-1511.

Casado-Vela, J., Sellés, S., Navarro-Pedreno, J., Bustamante, M.A., Mataix-Beneyto, J. and Gomez, I. 2006. Evaluation of composted sewage sludge as nutritional source for horticultural soils. Waste Management 26: 946-952.

Chen, F.J., Fang, Z.G., Gao, Q., Ye, Y.L., Jia, L.L., Yuan, L.X., Mi, G.H., Zhang, F.S. 2013. Evaluation of the yield and nitrogen use efficiency of the dominant maize hybrids grown in North and Northeast China. Science China Life Science 56: 552-560.

Christodoulakis, N.S. and Margaris, N.S. 1996. Growth of corn (Zea mays) and sunflower (Helianthus annuus) plants is affected by water and sludge from a sewage treatment plant. Bulletin of Environmental Contamination and Toxicology 57: 300-306.

Daur, I., Abusuwar, A.O. and Alghabari, F. 2015. Exploitation of EM.1-treated blend of organic resources and humic acid for organic berseem (Trifolium alexandrinum) production. Turkish Journal of Field Crops 20: 125-130.

Epstein, E., Taylor, J.M. and Chaney, R.L. 1976. Effects of sewage sludge and sludge compost applied to soil on some soil physical and chemical properties. Journal of Environmental Quality 5: 422-426.

Fixen, P.E. 2005. Understanding and improving nutrient use efficiency as an application of information technology. In: Proceedings of the Symposium on Information Technology in Soil Fertility and Fertilizer Management. A Satellite Symposium at the XV International Plant Nutrient Colloquium, Sep. 14-16, Beijing, China.

Jackson, M.L. 1973. Soil Chemical Analysis, Prentice Hall of India Private Limited, New Delhi.

Lindsay, W.L. and Norvell, W.A. 1978. Development of a DTPA soil test for zinc, iron, manganese and copper. Soil Science Society of America Journal 42: 421-428.

Mahdy, A.M., Elkhatib, E.A. and Fathi, N.O. 2007. Drinking water treatment residuals as an amendment to alkaline soils: Effects on the growth of corn and phosphorus extractability. International Journal of Environmental Sciences and Technology 4: 489-496.

Milkha, S.A. 2010. Integrated nutrient management for sustainable crop production, improving crop quality and soil health and minimizing environmental pollution. In: Soil Solutions for a Changing World. pp. 
301-317. $19^{\text {th }}$ World Congress of Soil Science, Brisbane, Australia.

Mitchell, M.J., Hartenstein, R., Swift, B.L., Neuhauser, E.F., Abrams, B.L., Mulligan, R.M., Brown, B.A., Craig, D. and Kaplan, D. 1978. Effects of different sewage sludges on some chemical and biological characteristics of soil. Journal of Environmental Quality 7: 55159.

Mosier, A.R., Syers, J.K. and Freney, J.R. 2004. Assessing the impacts of fertilizer use on food production and the environment. In: Agriculture and the Nitrogen Cycle. Scope-65, Island Press, London.

N'Dayegamiye, A. 2009. Soil properties and crop yields in response to mixed paper mill sludge, cattle manure and inorganic fertilizer application. Agronomy Journal 101: 826-835.

Paramasivam, S., Fortenberry, G.Z., Julius, A., Sajwan, K.S. and Alva, A.K. 2008. Evaluation of emission of greenhouse gases from soils amended with sewage sludge. Journal of Environmental Sciences and Health 43: 178-185.

Paulraj, C. and Sree Ramulu, U.S. 1994. Effect of soil application of low levels of urban sewage sludge on the uptake of nutrients and yield of certain vegetables. Journal of the Indian Society of Soil Science 42: 485-487.

Rathod, D.D., Rathod, P.H., Patel, K.P. and Patel, K.C. 2013. Integrated use of organic and inorganic inputs in wheatfodder maize cropping sequence to improve crop yields and soil properties. Archives of Agronomy and Soil Science 59: 1439-1455.

Sommers, L. 1977. Chemical composition of sewage sludges and analysis of their potential use as fertilizers. Journal of Environmental Quality 6: 225-239.

Tamrabet, L., Bouzerzour, H., Kribaa, M. and Makhlouf, M. 2009. The effect of sewage sludge application on durum wheat (Triticum durum). International Journal of Agriculture and Biology 11: $741-745$.

\section{How to cite this article:}

Auyoub Bhat, M., J.A. Wani and Sandeep Kumar. 2018. Influence of Composted Municipal Sludge on Efficiency of Primary Nutrients in Maize (Zea mays L.) under Temperate Himalayas. Int.J.Curr.Microbiol.App.Sci. 7(06): 907-915. doi: https://doi.org/10.20546/ijcmas.2018.706.107 